\section{Armchair biodiversity}

SIR - The word 'biodiversity' has become a popular symbol for arousing people's consciences about the extreme vulnerability of wild animals and plant populations. Thousands of pages have been devoted to equating 'biodiversity' with genetic diversity and interpreting it in terms of DNA. The problem of preserving biodiversity is frequently displayed as solely the task of collecting and storing the broadest number of different germplasms or DNA sequences to secure the future of species and the biological wealth of our world.

This armchair, molecular-biased approach is extremely dangerous, because real biodiversity is a consequence of diverse interactions between biological populations and environmental and anthropic factors. Wildlife preservation, the main component of biodiversity, has been successfully approached through monitoring of endangered species and by developing natural reserves and national parks. The problem becomes more complicated when synanthropic taxa are involved. Mankind has produced and driven biodiversity over thousands of years while interacting with domesticated plants and animals. Local cultivars cannot be simply stored without the understanding of the conscious and unconscious processes that led to their appearance and diffusion. Most of these processes ceased a long time ago in the so-called developed countries, with the transfer of these responsibilities from the local communities of peasants to specialized groups of technically qualified people. But cultivated plants and domesticated animals are so closely connected to the culture in which they arose that their survival is dependent on the survival of the culture. It is nothing new to hear about the extinction of cultivars or even cultivated species with the disappearance of the culture that raised them.

Extant aboriginal cultures, mainly illiterate, have been accumulating a considerable wealth of ecological knowledge and patterns of organisms adapted to their environments, and accordingly have produced a cohort of biodiversity in form of synanthropic plants and animals, which are now in a serious danger of loss because of the extensive and extremely intense acculturation imposed all over the world by unadaptive Western models.

Orally transmitted knowledge is extremely adaptive and dependent. Most of this information is understood only under the local environmental conditions by locally trained people, whereas Western efforts to collect in the short term the whole of aboriginal knowledge and patterns is biased by the importance NATURE · VOL 360 - 26 NOVEMBER 1992 given to the taxon-use, which is explained exclusively in terms of active substances or prospective economic benefits.

The survival of both ecological and cultural diversity is the sine qua non for a long-term preservation of biodiversity. Germplasm can be preserved by means of freezing. But how can environmental or cultural diversity be frozen?

\section{Diego Rivera-Núñez}

\section{Concepción Obón-de-Castro}

Departamento de Biologia Vegetal,

Universidad de Murcia,

30071 Murcia, Spain

SIR - While the Convention on Bioligical Diversity has the laudable goal of increasing the income of the poor countries, we have seen no public discussion in Nature or elsewhere of possible adverse consequences, particularly in countries where governments have ownership rights over plant (or other) species.

Payments by foreigners directly to governments or countries in which plant species are found could have a significant antidemocratic effect by providing a source of income independent of control by a country's citizens. In a democratic country, one important way in which citizens can control the government is through action to limit the amounts and use of governmental income that is obtained, for example, from taxes. Once governments have access to a significant source of income independent of its citizens, it reduces the control citizens may exert through their restriction of government access to money. A government could more easily take unpopular action because it would be less important whether citizens would willingly support such action.

It may be argued that 50 per cent (or some other percentage) of such monies will have to be applied to conservation. But what guarantees are there that countries will adhere to such restrictions? And what can be done if they don't? Invade them? Even if followed rigorously, this restriction still leaves a significant amount of discretionary income to governments. If these kinds of 'royalty' payments for use of plant species are to be made at all, we think it would be much safer, from a democratic point of view, to make them directly to a country's inhabitants, not to their rulers.

A good example of what might happen is what actually did happen in the case of the Organization of Petroleum Exporting Countries (OPEC). A country that 'owned' certain valuable plant species as a monopoly (or, in the case of dispute co-owned them along with a few other countries) could act as OPEC does. In OPEC countries, the politicians are far more eager to please the politicians of other OPEC countries than they are to please their own citizens, because the government's income depends to a far larger extent on the cooperation of the rulers of other OPEC countries than it does on that of their own citizens. Do we really want to see this model of governance spread to other countries? Developing countries are greatly in need of more democracy, not less.

\section{Durk Pearson}

Sandy Shaw

PO Box 2160

Tonopah, Nevada 89049, USA

\section{Missing the Moon}

SIR - Your leading article (Nature 358, $609 ; 1992)$ criticizing the obsession of the National Aeronautics and Space Administration (NASA) with an enormously expensive but unproductive manned space programme - while solemnly insisting that this obsession is a genuine mistake on NASA's part and that "everybody's interests, NASA's included, yould be better served" if it changed its ways - displays a rather touching innocence. The truth, as George Keyworth pointed out during his tenure as President Ronald Reagan's science adviser, is that NASA deliberately misleads Congress, the White House and the public far more than any other US government agency - and it does so simply because its most important real interest by far (like that of any other government agency) is to maintain its current size and employment level, while it has far less real justification for its continued existence at such current levels (left over from the days of the Moon race) than any other US government agency. Naturally, it will sensibly continue pulling the wool over congressional and executive eyes for as long as it can get away with it, which is likely to be for a very long time.

One way to improve the situation might be to strip NASA of all its ability to select space science projects (manned and unmanned) by transferring responsibility to other agencies such as the National Science Foundation, the National Institutes of Health, the National Oceanographic and Atmospheric Administration and the Departments of Commerce and the Interior but any real major improvement will come only when Congress and the White House contain a large number of people with a reasonable level of basic scientific knowledge, which I expect to see the week of the millennium.

\section{Bruce Moomaw}

2953 Oakleaf Drive,

Cameron Park, California 95632, USA 